\title{
Pengaruh Penambahan Inokulum Azotobacter sp. terhadap Pertumbuhan Tanaman Sorghum bicolor untuk Aplikasi Fitoremediasi
}

\section{Effect of Adding Azotobacter sp. Inoculum on the Growth of Sorghum bicolor for Fitoremediation Application}

\author{
Hanies Ambarsari ${ }^{1}$, Juli Elisa Udayani ${ }^{2}$, Mulyono ${ }^{1}$, dan Dominikus H. Akhadi ${ }^{1}$ \\ ${ }^{1}$ Balai Teknologi Pengolahan Air dan Limbah (BTPAL) - BPPT, Gedung 820 Geostech, Puspiptek Serpong, \\ Tangerang Selatan, Banten 15314. \\ ${ }^{2}$ Program Studi Mikrobiologi, Sekolah Ilmu dan Teknologi Hayati, Institut Teknologi Bandung, \\ Jalan Ganesha Bandung 40132 \\ Email: hanies.ambarsari@gmail.com
}

Diterima : 02 November 2015 Diperiksa :06 November 2015 Revisi : 25 November 2015 Disetujui :15 Desember 2015

\begin{abstract}
A laboratory scale study was conducted to determine the effect of Azotobacter sp. inoculum on the growth of Sorghum bicolor plant which will be applied in phytoremediation for marginal land having less water sources. The experimental treatment unit of Azotobacter inoculum sp., Urea, or a negative control was made by way of inoculating as many as $1 \mathrm{~mL}$ each into a $2 \mathrm{~kg}$ pot of soil containing Sorghum bicolor seeds. Each pot was then labeled with the sign "Az" for Azotobacter sp treatment, "U" for the Urea treatment, and " $K$ " for the negative control which was not added inoculum Azotobacter sp. or urea. Each treatment was made in five repetitions, so that in total there are 15 research pot units all were incubated for 14 days at the Greenhouse BTL-BPPT which was dry and exposed to sunlight. The plant height was measured every day during the 14 day study. The results showed that the addition of Azotobacter sp. and urea were influential in promoting the growth of S. bicolor. The "Az" gradient rise was higher than "U" showing that the effect of the inoculum Azotobacter sp. addition was higher than urea in enhancing the growth of S. bicolor. To test the significance of the effect of Azotobacter sp. inoculum on the growth of $S$. bicolor the analysis of variance (ANOVA) was conducted and the results show that the addition of inoculum Azotobacter sp. had significant effect on the height of S. bicolor plant.
\end{abstract}

Keywords: Azotobacter, biofertilizer, phytoremediation, sorghum bicolor, urea

\section{ABSTRAK}

Sebuah penelitian skala laboratorium dilakukan untuk menentukan pengaruh inokulum Azotobacter sp. terhadap pertumbuhan tanaman Sorghum bicolor yang akan diterapkan dalam usaha fitoremediasi lahan marginal yang kurang sumber air. Unit percobaan perlakuan inokulum Azotobacter sp., urea, atau kontrol negatif dibuat dengan cara menginokulasi sebanyak $1 \mathrm{~mL}$ masing-masing ke dalam pot berisi $2 \mathrm{~kg}$ tanah yang dibenami benih $S$. bicolor. Setiap pot kemudian dilabeli dengan tanda "Az" untuk perlakuan Azotobacter sp, "U" untuk perlakuan urea, dan "K" untuk kontrol negatif yang tidak ditambahkan inokulum Azotobacter sp. ataupun urea. Untuk masing-masing perlakuan dibuat 5 pengulangan, sehingga total semuanya ada 15 unit pot penelitian yang diinkubasi selama 14 hari di dalam Greenhouse BTL-BPPT yang kering dan terkena cahaya matahari. Tinggi tanaman S. bicolor diukur setiap hari selama 14 hari penelitian. Hasil penelitian menunjukkan bahwa penambahan Azotobacter sp. maupun urea berpengaruh dalam meningkatkan pertumbuhan $S$. bicolor. Gradien kenaikan Az lebih tinggi dibandingkan $U$, hal ini menunjukkan bahwa pengaruh penambahan inokulum Azotobacter sp. lebih tinggi dibandingkan urea dalam meningkatkan pertumbuhan S. bicolor. Untuk menguji signifikansi pengaruh Azotobacter sp. terhadap pertumbuhan S. bicolor maka analisis variansi (ANOVA) dilakukan dan hasilnya menunjukkan bahwa penambahan inokulum Azotobacter sp. berpengaruh signifikan terhadap tinggi tanaman S. bicolor.

Kata kunci: Azotobacter sp., biofertilizer, fitoremediasi, Sorghum bicolor, urea 


\section{PENDAHULUAN}

\subsection{Latar Belakang}

Azotobacter merupakan kelompok bakteri yang umum ditemukan saat diisolasi dari tanah dan diketahui memiliki aktivitas fiksasi nitrogen. Azotobacter merupakan kelompok genus bakteri kemoorganotrofik yang menginhabitasi tanah, umumnya pada tanah yang $\mathrm{pH}$ nya netral dan basa. Genus ini bersifat free-living. Sel bakteri genus Azotobacter berukuran besar dan berbentuk bola atau cocci. Banyak isolat Azotobacter yang ukurannya menyerupai ukuran ragi, yakni berdiameter $2-4 \mu \mathrm{m}$ atau lebih. Beberapa spesies motil menggunakan flagella peritrik. Saat tumbuh dengan $\mathrm{N}_{2}$ sebagai sumber nitrogen, kapsul ekstensif atau lapisan seperti lendir akan diproduksi oleh spesies bakteri pemfiksasi nitrogen untuk melindungi enzim nitrogenase pada sitoplasma. Hal ini karena Azotobacter merupakan aerob obligat walaupun nitrogenase sensitif terhadap $\mathrm{O}_{2}^{(1)}$. Lamakelamaan sel dapat kehilangan mobilitasnya dan berubah morfologinya menjadi bulat dan memproduksi lapisan mukus yang membentuk kapsul. Bentuk sel ini dipengaruhi asam amino glisin yang terdapat pada pepton terkandung dalam media nutrisi ${ }^{(2)}$.

Azotobacter merupakan bakteri aerob yang menerima energi dari reaksi redoks dengan menggunakan senyawa organik sebagai donor elektron. Nilai $\mathrm{pH}$ optimum untuk pertumbuhan dan fiksasi nitrogen Azotobacter sp. berkisar antara 7-7,5, namun pertumbuhannya dapat tetap berlangsung pada $\mathrm{pH} 4,8-8,5^{(3)}$. Azotobacter juga dapat tumbuh secara mixotroph, yakni dalam medium nitrogen-free yang mengandung mannosa ${ }^{(4)}$. Azotobacter dapat hidup pada karbohidrat yang variatif, alkohol, dan asam organik, serta metabolismenya oksidatif. Semua spesies Azotobacter memfiksasi nitrogen tapi beberapa dapat tumbuh pada sumber nitrogen campuran yang sederhana. Azotobacter dapat membentuk struktur kista yang mirip dengan endospora bakteri, yakni menunjukkan respirasi endogenous yang signifikan dan resisten terhadap desikasi, disintegrasi mekanik, serta radiasi ion maupun UV. Berbeda dengan endospora, kista Azotobacter tidak terlalu resisten terhadap panas dan tidak sepenuhnya dorman karena mengoksidasi sumber $C$ secara cepat ${ }^{(1)}$.

Azotobacter telah banyak diteliti untuk dibuat sebagai penyusun biofertilizer. Biofertilizer merupakan pupuk biologis yang terbuat dari inokulum mikroba pemfiksasi nitrogen dan prospeknya sangat tinggi karena lebih ramah lingkungan. Beberapa laporan menyatakan penggunaan pupuk kimiawi berkelanjutan dapat merusak karakteristik alami tanah, air tanah, dan memberikan polusi udara ${ }^{(5)}$. Penelitian-penelitian sebelumnya juga telah menyatakan bahwa penggunaan biofertilizer dari Azotobacter pada tanaman-tanaman C4 seperti sorghum (Sorghum bicolor), bawang, dan gandum menunjukkan pertumbuhan yang lebih tinggi.

Sorghum bicolor merupakan tanaman padipadian yang menghasilkan yield biomassa yang tinggi dan tidak membutuhkan banyak air agar bisa tumbuh, karenanya bisa tumbuh baik di daerah yang kering dan akarnya bila terdekomposisi dapat menjadi biofertilizer yang baik dan menggemburkan tanah ${ }^{(6)}$. Tanaman $S$. bicolor merupakan tanaman $\mathrm{C} 4$ sehingga mampu tumbuh di area yang terlalu kering. Jika berada pada kondisi yang tidak menguntungkan $S$. bicolor dapat menjadi dorman dan dapat melanjutkan pertumbuhannya bahkan setelah beradaptasi dengan kondisi kekeringan atau minim air ${ }^{(7)}$. Tanaman $S$. bicolor dapat beradaptasi dengan jenis tanah yang beragam, dari tanah berpasir hingga tanah liat. Walaupun demikian sumber air tetap diperlukan untuk pertumbuhan S. bicolor. Akar S. bicolor yang dalam di tanah dapat mengekstraksi air dari sumber yang rendah serta dapat tumbuh di tanah dengan $\mathrm{pH}$ kisaran 5-8,5. Benih S. bicolor perlu diberi senyawa fungisida atau insektisida sebelum ditanam dan umumnya ditanam pada kedalaman $4-5 \mathrm{~cm}^{(7)}$. Benih $S$. bicolor dapat diberi klor sebagai senyawa fungisida yang menghambat kontaminasi fungi dan ditanam 4-5 $\mathrm{cm}$ dari permukaan tanah. Tanah juga tetap disiram setiap hari dengan jumlah air yang tidak terlalu banyak agar $S$. bicolor dapat tumbuh optimum.

Tanaman S. bicolor juga diketahui berperan dalam fitoremediasi. Ketika ditumbuhkan dalam tanah yang mengandung beragam logam berat, seperti As, Cd, Co, Cu, dan Zn terlihat bahwa $S$. bicolor mampu mengekstrak logam selama siklus pertumbuhannya. Penambahan fertilizer dan substrat nutrisi ke tanah yang mengandung logam sebagai media tumbuh $S$. bicolor ditemukan tidak meningkatkan konsentrasi logam pula $^{(8)}$. Oleh sebab itu perlu dilakukan penelitian terhadap pengaruh penambahan inokulum Azotobacter sp. sebagai biofertilizer terhadap pertumbuhan tanaman $S$. bicolor yang diketahui sangat potensial untuk fitoremediasi pada tahan yang terkontaminasi limbah logam berat.

\subsection{Tujuan}

Tujuan dari penelitian ini adalah untuk menentukan pengaruh inokulum Azotobacter sp. terhadap pertumbuhan tanaman Sorghum bicolor 
yang akan diterapkan dalam usaha fitoremediasi lahan tercemar logam berat.

\section{BAHAN DAN METODE}

Penelitian ini dilakukan di Laboratorium Mikrobiologi dan Laboratorium Fitoteknologi, Balai Teknologi Pengolahan Air dan Limbah (BTPAL) - BPPT selama bulan Juni dan Juli 2014. Tahapan, alat, bahan dan metode yang dilakukan adalah seperti yang diuraikan berikut ini.

\subsection{Pembuatan Inokulum Azotobacter sp.}

Alat yang dibutuhkan untuk membuat inokulum Azotobacter sp. adalah oose, bunsen, labu Erlenmeyer $500 \mathrm{~mL}$, dan shaker. Bahan yang dibutuhkan, antara lain kultur murni Azotobacter sp., medium Azoto Broth, dan kapas lemak. Untuk membuat inokulum Azotobacter sp. dengan kepadatan sel $10^{6} \mathrm{CFU} / \mathrm{ml}$, maka kultur awal dari stok diinokulasikan sebanyak $28 \mathrm{~mL}$ ke dalam medium Azoto Broth $500 \mathrm{~mL}$, lalu diinkubasi pada shaker dengan agitasi sehingga diperoleh inokulum Azotobacter sp. yang baru. Kepadatannya kemudian dihitung dengan metode TPC (Total Plate Count).

\subsection{Total Plate Count Pour-Plate Method}

Alat yang dibutuhkan untuk melakukan TPC pada pelat yang dituang adalah cawan petri, tabung reaksi, botol Scott $100 \mathrm{ml}$, mikropipet, dan gelas ukur $10 \mathrm{~mL}$. Bahan yang dibutuhkan, antara lain akuades steril, medium Nutrient Agar (NA) dan inokulum awal Azotobacter sp. Kultur Azotobacter sp diinokulasikan sebanyak $1 \mathrm{~mL}$ ke akuades $9 \mathrm{~mL}$, lalu diencerkan berseri dengan akuades hingga mencapai $10^{-7}$. Kemudian yang pengenceran $10^{-6}$ dan $10^{-7}$ diinokulasikan sebanyak $1 \mathrm{~mL}$ ke cawan petri yang sudah diisi dengan medium NA secara pour-plate method dan diinkubasi pada suhu ruang selama 24 jam. Hasil pengamatan dihitung jumlah koloninya dengan metode Total Plate Count.

\subsection{Pengamatan Mikroskopis Sel Inokulum Azotobacter sp.}

Alat yang dibutuhkan untuk melakukan pengamatan mikroskopis sel dari inokulum Azotobacter sp., antara lain pembakar bunsen, oose, kaca objek, dan mikroskop. Mikroskop yang digunakan adalah mikroskop cahaya. Bahan yang dibutuhkan, antara lain alkohol 70\%, akuades, dan perlengkapan untuk pewarnaan Gram seperti pewarna crystal violet, safranin, lugol, dan alkohol 96\%. Pengamatan mikroskopis sel inokulum Azotobacter sp. dilakukan dengan mengambil secuplik inokulum dari cawan petri menggunakan oose secara aseptic, lalu dibuatlah preparat kering di atas gelas obyek. Setelah diberi perlakuan pewarnaan Gram sesuai dengan prosedur kerja yang telah tersedia, maka preparat itu kemudian diamati di bawah mikroskop dengan perbesaran 100x. Hasil pengamatan kemudian dicatat dan direkam fotonya menggunakan kamera yang sudah tersedia pada mikroskop.

\subsection{Perlakuan Penambahan Inokulum Azotobacter sp. dan Urea terhadap Pertumbuhan Sorghum bicolor}

Alat yang dibutuhkan untuk menginokulasi inokulum Azotobacter sp. dan urea ke masingmasing $S$. bicolor, antara lain mikropipet ukuran 100-1.000 $\mu \mathrm{L}$ dan spatula. Bahan yang dibutuhkan, antara lain tips, aluminium foil, inokulum Azotobacter sp., dan urea. Unit percobaan perlakuan inokulum Azotobacter sp., urea, atau kontrol negatif dibuat dengan cara menginokulasi sebanyak $1 \mathrm{~mL}$ masing-masing ke dalam pot berisi $2 \mathrm{~kg}$ tanah yang dibenami benih Sorghum bicolor. Setiap pot kemudian dilabeli dengan tanda "Az" untuk perlakuan Azotobacter sp, "U" untuk perlakuan urea, dan "K" untuk kontrol negatif yang tidak ditambahkan inokulum Azotobacter sp. ataupun urea. Untuk masingmasing perlakuan dibuat 5 pengulangan, sehingga total semuanya ada 15 unit pot penelitian yang diinkubasi selama 14 hari di dalam Greenhouse BTL-BPPT yang kering dan terkena cahaya matahari. Tinggi tanaman $S$. bicolor diukur setiap hari selama 14 hari penelitian. Data hasil pengamatan kemudian dianalisa dan disajikan ke dalam grafik untuk dibandingkan satu sama lain dan dibuat kesimpulannya.

\section{HASIL DAN PEMBAHASAN}

\subsection{Total Plate Count Pour Plate Method}

Analisis data dari hasil pengamatan TPC menggunakan pour-plate method menggunakan rumus:

Konsentrasi sel $(\mathrm{CFU} / \mathrm{ml})^{(1)}=\frac{\text { Jumlah koloni yang tumbuh }}{\text { Tingkat pengenceran }}$

Hasil pengamatan pada Tabel 1 menunjukkan pada tingkat pengenceran $10^{-6}$ tumbuh koloni sebanyak 20 dan 22, sedangkan pada tingkat pengenceran $10^{-7}$ tumbuh koloni sebanyak 1 dan 2. Rata-rata dari hasil TPC tersebut menunjukkan hasil konsentrasi sel pada kultur awal sebesar $1,8 \times 10^{7} \mathrm{CFU} / \mathrm{ml}$ (Gambar 1).

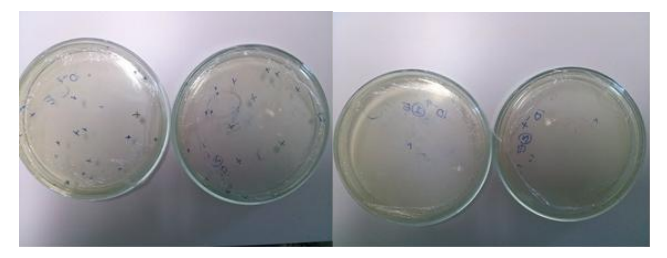


Gambar 1. Koloni hasil TPC pour-plate method pengenceran $10^{-6}$ dan $10^{-7}$

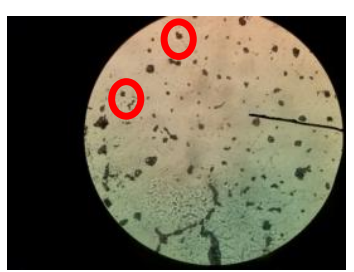

Gambar 2. Pewarnaan gram Azotobacter sp.

Tabel 1. Hasil pengamatan TPC Pour-Plate Method

\begin{tabular}{c|c|c}
\hline Tingkat Pengenceran & Pelat I & Pelat II \\
\hline $10^{-6}$ & 20 & 22 \\
\hline $10^{-1}$ & 1 & 2 \\
\hline
\end{tabular}

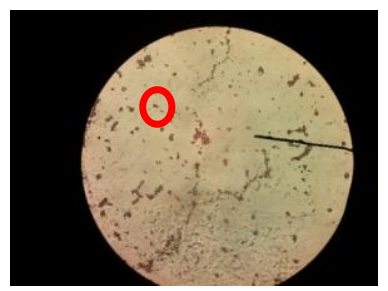

Gambar 3. Pewarnaan gram Azotobacter sp.

Gambar 1 adalah hasil pengamatan koloni yang tumbuh setelah TPC pour-plate method yang menunjukkan bahwa koloni dominan yang tumbuh berwarna putih krem dan memiliki tekstur yang flat. Beberapa di antara koloni tersebut berwarna kuning dan coklat. Hal ini menunjukkan ketersesuaian dengan literatur ${ }^{(9)}$ yang menyebutkan bahwa Azotobacter memproduksi koloni yang flat berwarna putih krem. Koloni juga dapat berwarna coklat, hijau, dan tidak berwarna bergantung kepada spesiesnya.

\subsection{Pengamatan Mikroskopis Sel pada Inokulum Azotobacter sp.}

Pengamatan mikroskopis sel dari inokulum Azotobacter sp. dilakukan dengan diberi pewarnaan Gram, lalu diamati menggunakan mikroskop cahaya.

Gambar 2 dan 3 menunjukkan bahwa sel terlihat berupa Gram-positif dan bentuknya ada yang batang (basil) maupun bulat (coccus). Hal ini menunjukkan adanya ketersesuaian dengan literatur ${ }^{(10),(11)}$ yang menyatakan bahwa genus Azotobacter umumnya berbentuk variatif dari basil hingga bulat.

Diketahui pula bahwa spesies Azotobacter umumnya merupakan bakteri Gram-negatif sehingga tidak sesuai dengan hasil pengamatan di laboratorium yang menunjukkan sel Azotobacter sp. berwarna keunguan, yakni Gram-positif. Hal ini diperkirakan merupakan produksi varian Gram-positif oleh Azotobacter chroococcum karena diketahui bahwa bentuk Gram-positif dari kultur Azotobacter chroococcum serupa dengan basil berspora yang mampu hidup di medium yang tidak mengandung sumber nitrogen, sehingga disimpulkan bentuk Grampositif ini merupakan varian dari Azotobacter $\mathrm{sp}^{(11)}$.

\subsection{Pengaruh Penambahan Inokulum Azotobacter sp. terhadap Tinggi Tanaman Sorghum bicolor}

Tinggi tanaman $S$. bicolor diamati setiap harinya setelah ditambahkan inokulum Azotobacter sp., dibandingkan dengan perlakuan yang diberi urea dan kontrol negatif yang tidak diberi inokulum Azotobacter sp. maupun urea (Gambar 4 \& 5).

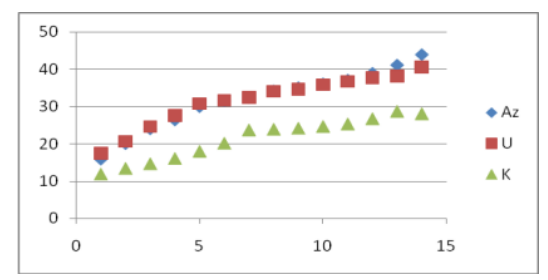

Gambar 4. Pengaruh penambahan inokulum Azotobacter sp. terhadap tinggi tanaman Sorghum bicolor

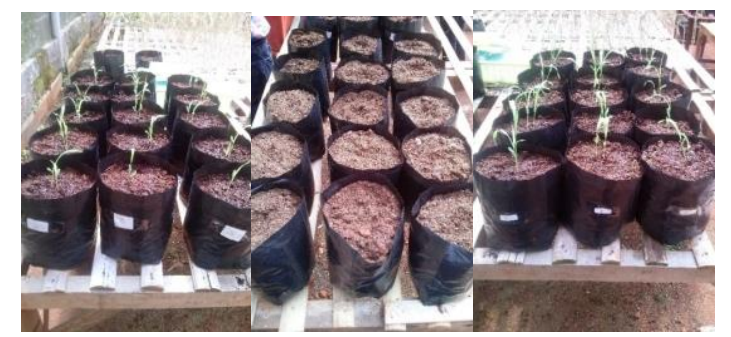

Gambar 5. Pengamatan tinggi tanaman Sorghum bicolor setiap hari selama 14 hari

Selama 14 hari data tinggi tanaman tiap perlakuan dikumpulkan dan dianalisis sehingga diperoleh grafik seperti yang terlihat di Gambar 4. Gambar 4 menunjukkan grafik pengaruh penambahan inokulum Azotobacter sp. (Az) terhadap kenaikan tinggi tanaman $S$. bicolor per hari selama 14 hari dibandingkan dengan penambahan urea $(U)$ dan kontrol negatif $(K)$, yakni tanpa penambahan urea dan inokulum. Grafik pada Gambar 4 menunjukkan bahwa garis grafik $\mathrm{Az}$ dan $\mathrm{U}$ berada di atas $\mathrm{K}$ yang menunjukkan penambahan Azotobacter sp. maupun urea berpengaruh dalam meningkatkan pertumbuhan S. bicolor. Gradien kenaikan Az lebih tinggi dibandingkan $U$, hal ini menunjukkan bahwa pengaruh penambahan inokulum Azotobacter sp. lebih tinggi dibandingkan urea 
dalam meningkatkan pertumbuhan $S$. bicolor. Hasil ini mempunyai ketersesuaian dengan hasil penelitian Van Oosterom dkk. ${ }^{(12)}$ yang membandingkan antara pemakaian pupuk kimia dengan bio-fertilizers yang mengandung mikroba Azotobacter sp. Dalam penelitian mereka, diketahui bahwa pemberian pupuk kimia sumber nitrogen berpengaruh signifikan terhadap indeks luas daun (LAI = Leaf Area Index) dan pertumbuhan tunas pada sorghum, sedangkan pemberian bio-fertilizers seperti bakteria Azotobacter dan Azospirillum mempunyai efek positif terhadap yield sorghumnya. Selain itu, dari hasil penelitian lain sebelumnya juga diketahui bahwa penggunaan pupuk biologis yang mengandung Azotobacter sp. dapat mengurangi secara signifikan konsumsi dari pupuk kimia, juga mengurangi efek berbahaya pupuk kimia terhadap lingkungan sekitar tanaman, sehingga meningkatkan kualitas tanamannya ${ }^{(13)}$.

Untuk menguji signifikansi pengaruh Azotobacter sp. terhadap pertumbuhan S. bicolor maka analisis variansi (ANOVA) digunakan dan hasilnya seperti yang dapat dilihat pada Tabel 2.

Tabel 2. Analisis variansi pengaruh penambahan inokulum Azotobacter sp. terhadap tinggi tanaman Sorghum bicolor

\begin{tabular}{c|c|c|c|c}
\hline $\begin{array}{c}\text { Sumber } \\
\text { Variansi }\end{array}$ & $\begin{array}{c}\text { Jumlah } \\
\text { Kuadrat }\end{array}$ & $\begin{array}{c}\text { Derajat } \\
\text { Kebebasan }\end{array}$ & $\begin{array}{c}\text { Rataan } \\
\text { Kuadrat }\end{array}$ & Fhit \\
\hline Perlakuan & 1005,4 & 2 & 502,7 & 4,25 \\
\hline Galat & 1301,1 & 11 & 118,3 & Ftabel \\
\hline Total & 2306,5 & 13 & & 3,98 \\
\hline
\end{tabular}

Hasil analisis variansi pada Tabel 2 menunjukkan bahwa nilai F-tabel lebih besar dibanding F-hitung, yakni F-tabel sebesar 3,98 dan F-hitung sebesar 4,25. Hal ini menunjukkan bahwa penambahan inokulum Azotobacter sp. berpengaruh signifikan terhadap tinggi tanaman S. bicolor. Hasil dari penelitian ini sesuai dengan hasil yang telah diperoleh oleh peneliti lainnya bahwa pertumbuhan tanaman $S$. bicolor dapat ditingkatkan dengan penambahan inokulum Azotobacter chroococcum ${ }^{(14)}$.

Hasil-hasil penelitian ini juga memiliki ketersesuaian dengan penelitian sebelumnya yang menunjukkan bahwa Azotobacter sp terbukti mampu menambah tinggi tanaman, jumlah daun, persentase diameter tunas dari pengisian bibit dan berat kering bibit pada tanaman Helianthus annuus ${ }^{(15)}$, juga dapat meningkatkan fisiologi dan morfologi akar pada tanaman padi ${ }^{(16)}$. Azotobacter sp. ini juga diketahui mampu meningkatkan kandungan karbohidrat dan klorofil pada tumbuhan sorghum forage (Speedfeed hybrid) ${ }^{(17)}$, serta germinasi bibit dan pertumbuhan tanaman rumputrumputan seperti jagung dan gandum dengan memproduksi vitamin-vitamin B, NAA, GA, dan bahan-bahan kimia lainnya (hormon tumbuhan) yang menghalangi berkembangbiaknya patogen pada akar ${ }^{(18)}$.

Genus Azotobacter diketahui memainkan peranan penting dalam siklus nitrogen di alam karena mempunyai fungsi metabolik yang bervariasi dan mendukung pertumbuhan tanaman $^{(19)}$, misalnya berperan dalam fiksasi nitrogen, mampu produksi vitamin-vitamin seperti thiamine dan riboflavin, hormon-hormon tanaman viz, indole acetic acid (IAA), gibberellins (GA) dan cytokianins (CK). Anggota dari genus Azotobacter seperti $A$. chroococcum, $A$. vinelandii, $A$. beijerinckii, $A$. nigricans, $A$. armeniacus, dan $A$. paspali banyak dipakai sebagai bio-fertilizers untuk berbagai jenis tanaman seperti wheat, oat, barley mustard, seasum, padi, linseeds, bunga matahari, castor, jagung, sorghum, kapas, jute, sugarbeets, tembakau, teh, kopi, karet, dan kelapa ${ }^{(20)}$.

\section{KESIMPULAN DAN SARAN}

Dari data yang sudah diperoleh dapat disimpulkan bahwa perlakuan inokulum Azotobacter sp. berpengaruh signifikan terhadap pertumbuhan tanaman Sorghum bicolor. Kepadatan sel inokulum Azotobacter sp. adalah $1,8 \times 10^{7} \mathrm{CFU} / \mathrm{ml}$ dengan morfologi sel Azotobacter sp. berbentuk basil dan coccus berkapsul serta merupakan Gram-positif.

Isolat Azotobacter sp. sebaiknya diidentifikasi lebih spesifik lagi, lewat identifikasi DNA atau uji biokimia untuk memastikan spesies dan genus isolat. Sebaiknya penyimpanan kultur murni isolat juga terus dijaga, disub-kultur secara berkala dan disimpan di suhu $-80^{\circ} \mathrm{C}$. Pengujian di lapangan juga sebaiknya lebih diperhatikan karena banyak faktor lingkungan seperti suhu, cahaya matahari, kelembapan, dan lainnya yang juga berpengaruh pada proses pertumbuhan tanaman S. bicolor ini.

\section{PERSANTUNAN}

Ucapan terima kasih penulis sampaikan kepada Balai Teknologi Pengolahan Air dan Limbah (BTPAL) yang telah mendukung persiapan, pelaksanaan penelitian dan sampai terwujudnya tulisan ini.

\section{DAFTAR PUSTAKA}

1. Madigan, T., J. M. Martinko, D. A. Stahl, and D. P. Clark, (2012), Brock: Biology of Microorganisms $13^{\text {th }}$ Ed. San Fransisco: Benjamin Cunnings. p. 674-678

2. Page, W.J. and A. Cornish, (1993), Growth of Azotobacter vinelandii UWD in fish peptone medium and simplified extraction of poly- $\beta$ - 
hydroxylbutyrate, Applied and Environmental Microbiology 59 (12): 4236-4244.

3. George, M., (2005), Bergey's Manual of Systematic Bacteriology, The Proteobacteria (2 ed.). New York: Springer.

4. Maier R. J. \& T. Y. Wong, (1985), H2Dependent mixotrophic growth of $\mathrm{N}_{2}$-Fixing Azotobacter vinelandii, Journal of Bacteriology 163 (2): 528-533.

5. Todar, Kennet. (2008). Important Groups of Procaryotes (page 5). http://textbookofbacteriology.net/procaryotes 5.html. Diakses 15 Juli 2014 pukul 19.00.

6. Torbert, H.A., S.A. Prior, H.H. Rogers, C.W. Wood, (2000), Review of elevated atmospheric $\mathrm{CO} 2$ effects on agroecosystems: residue decomposition processes and soil C-storage, Plant and Soil 224 (1): 59-73.

7. Skerman, P.J. and F. Riveros, (1990), Tropical

Grasses.http://www.fao.org/ag/agp/agpc/doc/ gbase/data/pf000319.htm. Diakses pada 22 Agustus 2014 pukul 20:46.

8. Marchiol, L., G. Fellet, D. Perosa, and Zerbi, G. (2007), Removal of trace metals by Sorghum bicolor and Helianthus annuus in a site polluted by industrial wastes: A field experience, Plant Physiology and Biochemistry 45(5): 379-397.

9. Arimurti, S. and E. Utarti, (2006), Isolasi, identifikasi dan karakterisasi Azotobacter galur indigenous asal pertanaman tebu di Jember sebagai pupuk hayati nitrogen. Laporan Penelitian Dosen Muda Jurusan Biologi, Fakultas MIPA, Universitas Negeri Jember, Jawa Timur.

10. Anonim, (2003), Azotobacter, World of Microbiology and Immunology, Encyclopedia.com. http://www. encyclopedia.com, diakses 8 Januari 2016.

11. Bisset, K. A., M.F. Hale,, M.H. Jeynes, and Lawrence, J.C. (1957), The production of Gram-positive variants by Azotobacterchroococcum, Journal of General Microbiology 16:572-575.

12. Van Oosterom E.J., A.K. Borrell, S.C. Chapman, and G.L.Hammer, (2010), Functional dynamics of the nitrogen balance of Sorghum: I. N demand of vegetative plant parts. Field Crop Research 155: 19-28.
13. Sardrood S.N.E., Y. Raei, A.B. Pirouz, B. Shokati, (2013), Effect of chemical fertilizers and bio-fertilizers application on some morpho-physiological characteristics of forage sorghum, International Journal of Agronomy and Plant Production 4 (2): 223231.

14. El-Batanony, N., (2009), Improvement of Sorghum bicolor L. growth and yield in response to Azotobacter chroococcum, compost water extract and arbuscular mycorrhiza fungi: Different application methods, New Egyptian Journal of Microbiology 23 (01): 127-144.

15. Dhanasekar, R., and R. Dhandapani, (2012), Effect of biofertilizers on the growth of Helianthus annuus. International Journal of Plant, Animal, and Environmental Sciences 2: 143-147.

16. Choudhury, M.A. and I.R. Kennedy, (2004), Prospects and potentials for system of biological nitrogen fixation in sustainable rice production, Biology and Fertility of Soils 39 : 219-227.

17. Mir, S., A. Sirousmehr, E. Shirmohammadi, (2015), Effect of nano and biological fertilizers on carbohydrate and chlorophyll content of forage sorghum (Speedfeed hybrid), International Journal of Biosciences (IJB) 6 (4): 157-164.

18. Mazid, M. and T.A. Khan, (2014), Future of Bio-fertilizers in Indian Agriculture: An Overview, International Journal of Agricultural and Food Research 3 (3): 10-23.

19. Sahoo, R.K., M.W. Ansari, T.K. Dangar, S. Mohanty, and N. Tuteja, (2013), Phenotypic and molecular characterization of efficient nitrogen fixing Azotobacter strains of the rice fields, Protoplasma doi: 10.1007/s00709-0130547-2.

20. Bhardwaj, D., M.W. Ansari, R.K. Sahoo, and N. Tuteja, (2014), Biofertilizer function as key player in sustainable agriculture by improving soil fertility, plant tolerance and crop productivity, Microbial Cell Factories 13: 66. (http://www.microbialcellfactories.com/conten $\mathrm{t} / 13 / 1 / 66$ 